Erratum

\title{
Erratum to "Influence of Vitamin D Binding Protein on Accuracy of 25-Hydroxyvitamin D Measurement Using the ADVIA Centaur Vitamin D Total Assay"
}

\author{
James Freeman, Kimberly Wilson, Ryan Spears, Victoria Shalhoub, and Paul Sibley \\ Siemens Healthcare Diagnostics, 511 Benedict Avenue, Tarrytown, NY 10591, USA \\ Correspondence should be addressed to James Freeman; james.freeman@siemens.com \\ Received 8 September 2014; Accepted 19 October 2014; Published 30 October 2014 \\ Copyright (C) 2014 James Freeman et al. This is an open access article distributed under the Creative Commons Attribution License, \\ which permits unrestricted use, distribution, and reproduction in any medium, provided the original work is properly cited.
}

The graphs in Figure 4(b) appear as duplicates of graphs in Figure 4(a) and are corrected as follows. 
Dialysis

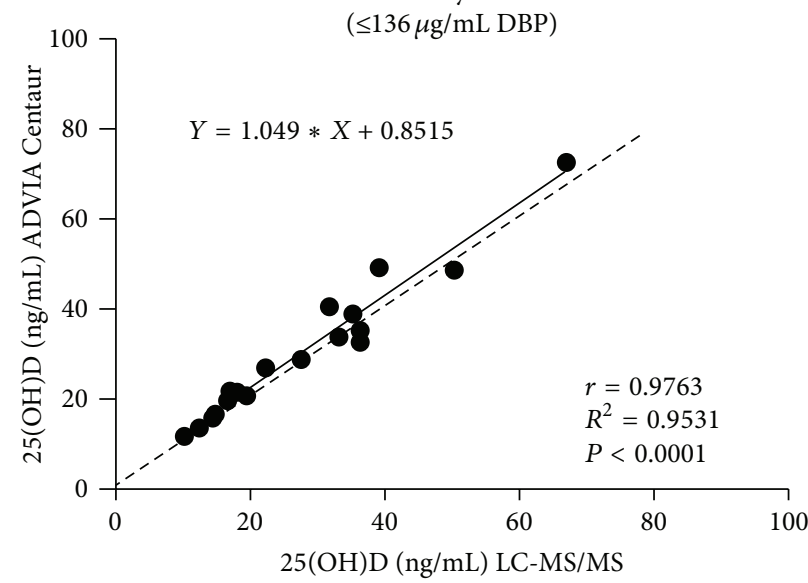

Dialysis

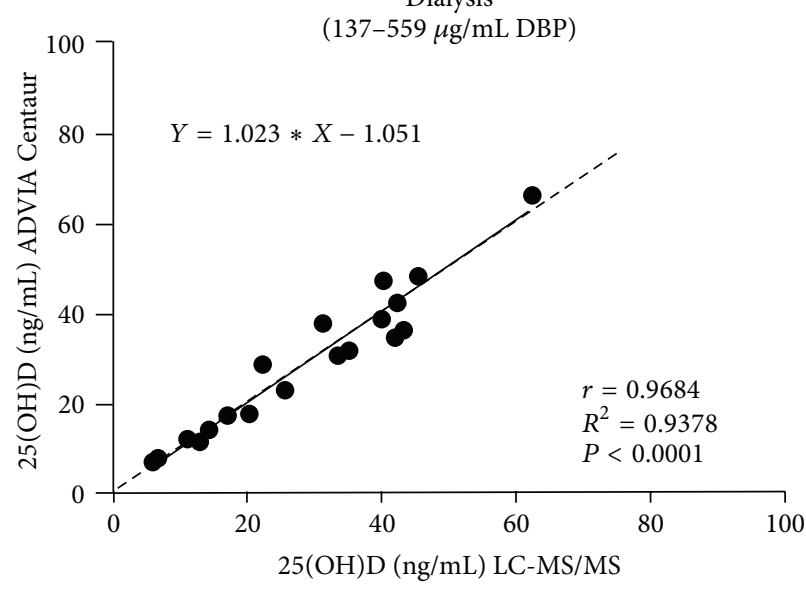

(b)

FIGURE 4 


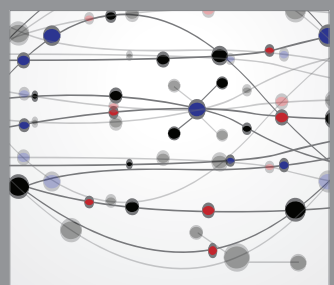

The Scientific World Journal
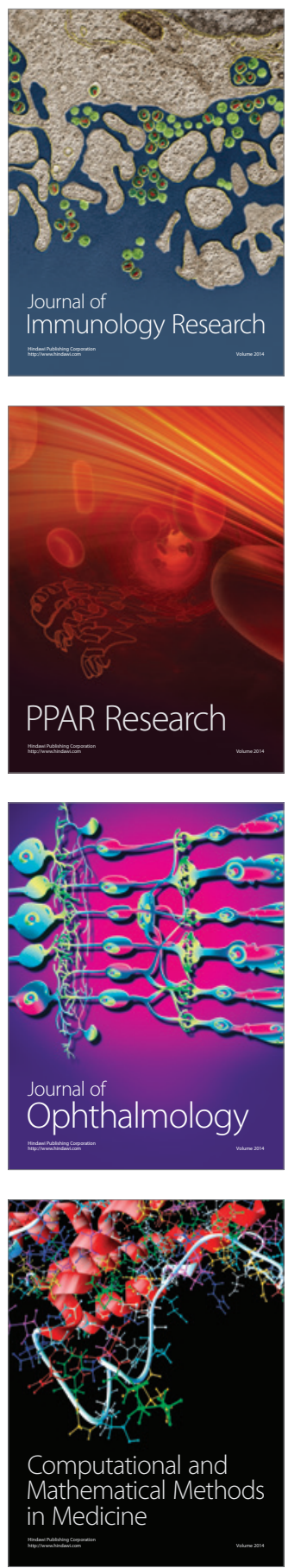

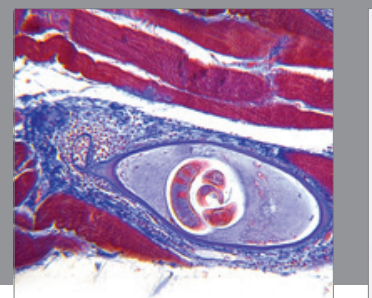

Gastroenterology

Research and Practice
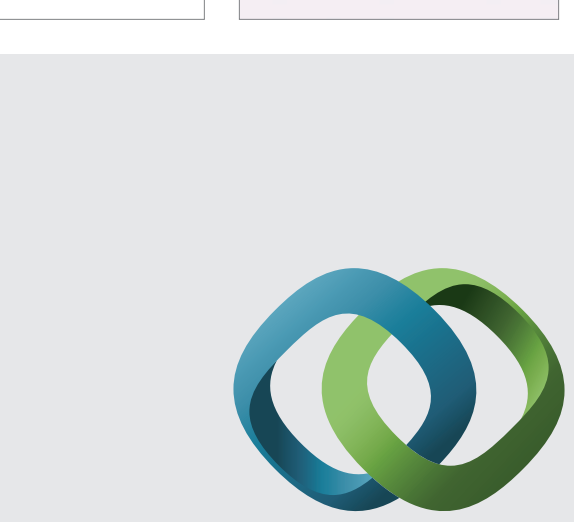

\section{Hindawi}

Submit your manuscripts at

http://www.hindawi.com
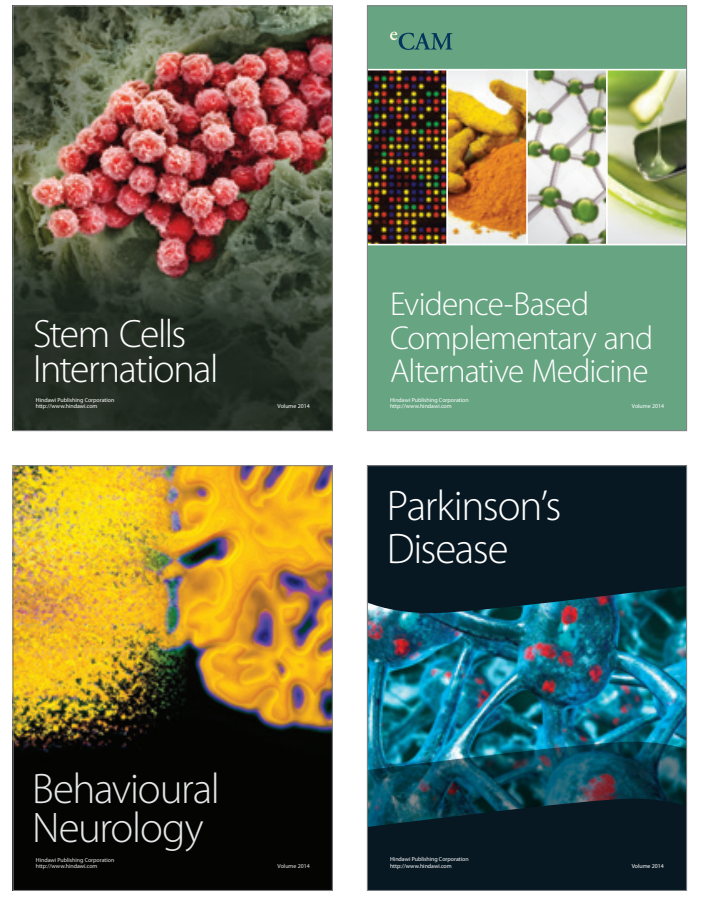
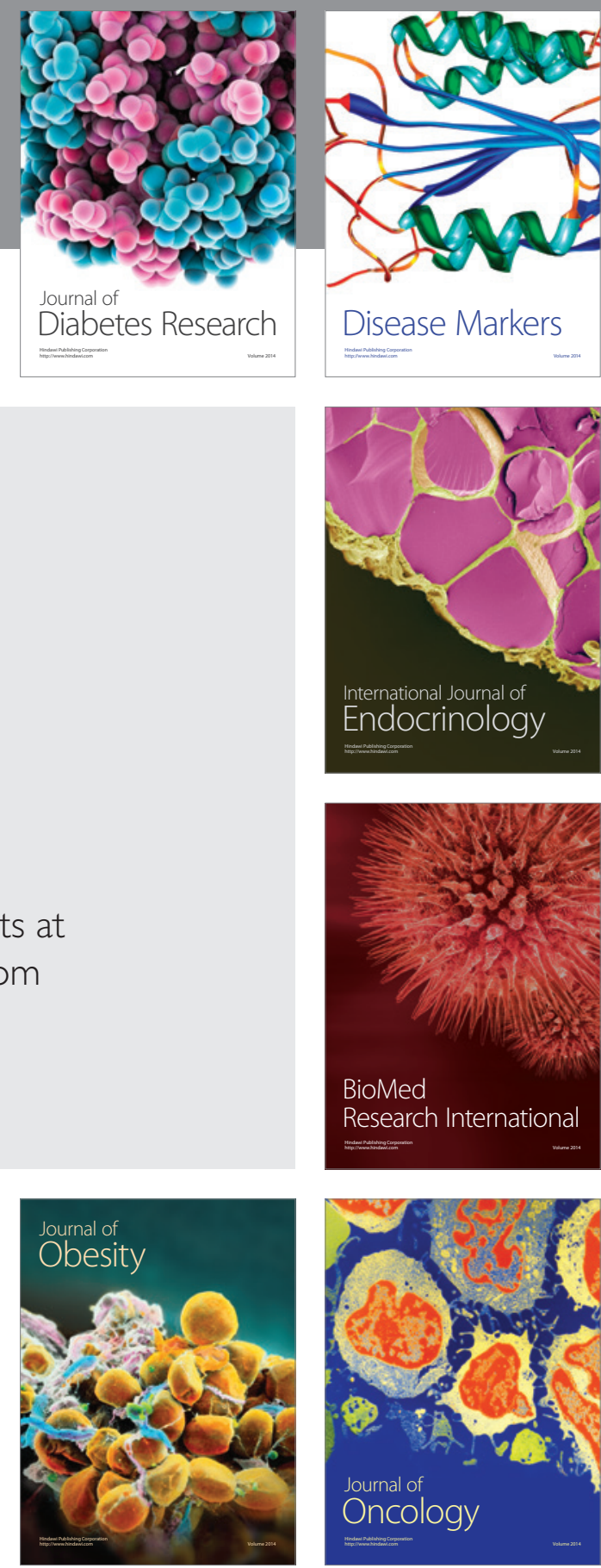

Disease Markers
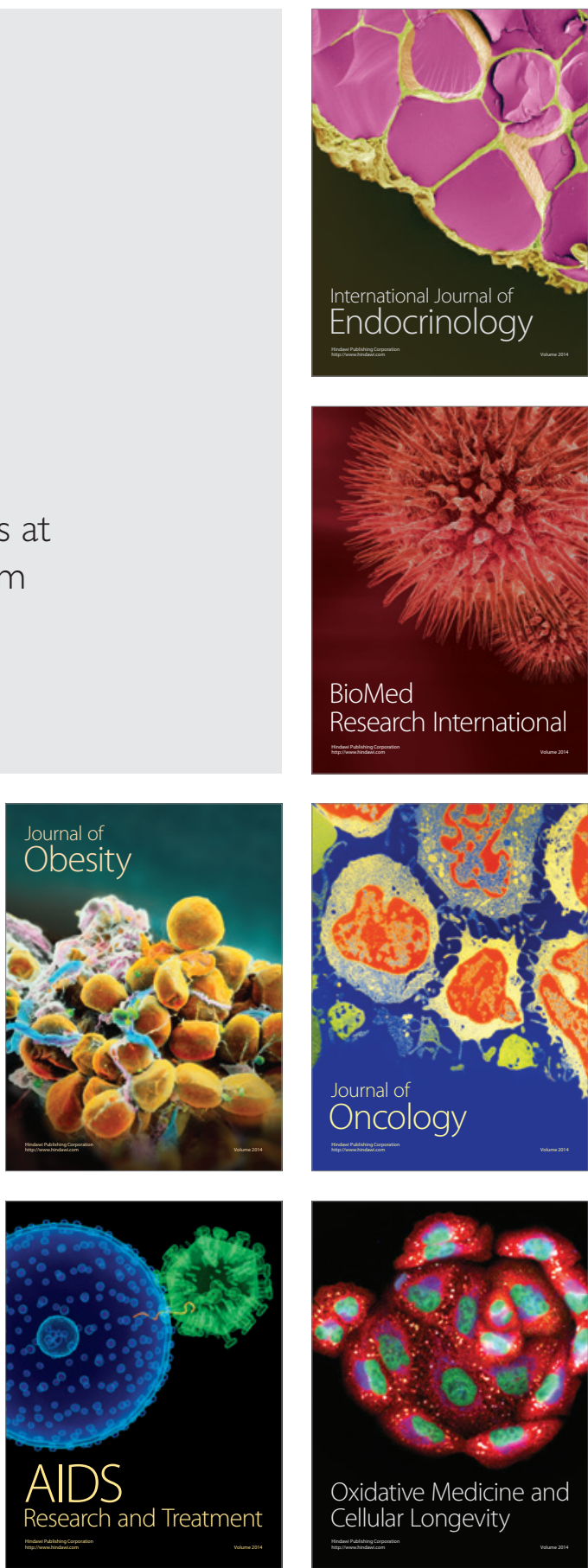